\title{
Influence of the Storage of Cistus ladanifer L. Bales from Mechanised Harvesting on the Essential Oil Yield and Qualitative Composition
}

\author{
Irene Mediavilla ${ }^{1, *(D)}$, María Amparo Blázquez ${ }^{2} \mathbb{1},{\text { Alex } \text { Ruiz }^{3} \text { and Luis Saúl Esteban }}^{1}$ \\ 1 CEDER-CIEMAT, Autovía de Navarra A-15, Salida 56, 42290 Lubia, Soria, Spain; luis.esteban@ciemat.es \\ 2 Departament de Farmacologia, Facultat de Farmàcia, Universitat de València, \\ Avda. Vicent Andrés Estellés s/n, 46100 Burjasot, Valencia, Spain; amparo.blazquez@uv.es \\ 3 CHROMESSENCE, C./Pompeu Fabra 25, La Garriga, 05530 Barcelona, Spain; alex.ruiz@chromessence.com \\ * Correspondence: irene.mediavilla@ciemat.es; Tel.: +34-97-528-1013
}

Citation: Mediavilla, I.; Blázquez, M.A.; Ruiz, A.; Esteban, L.S. Influence of the Storage of Cistus ladanifer $\mathrm{L}$. Bales from Mechanised Harvesting on the Essential Oil Yield and Qualitative Composition. Molecules 2021, 26, 2379 https://doi.org/10.3390/

molecules 26082379

Academic Editor: Maurizio Battino

Received: 16 March 2021

Accepted: 15 April 2021

Published: 19 April 2021

Publisher's Note: MDPI stays neutral with regard to jurisdictional claims in published maps and institutional affiliations.

Copyright: () 2021 by the authors. Licensee MDPI, Basel, Switzerland. This article is an open access article distributed under the terms and conditions of the Creative Commons Attribution (CC BY) license (https:// creativecommons.org/licenses/by/ $4.0 /)$.

\begin{abstract}
Cistus ladanifer is a Mediterranean native plant from which valuable products, such as essential oil, are obtained. Manual harvesting of the plants in wild shrublands is usual during short periods of time. Their mechanised harvesting could increase the volume of harvested plants and prevent fires, further storage of the plants collected being necessary. The objective of this work is to study the influence of the storage period of mechanically harvested bales on the essential oil yield and qualitative composition. The harvesting trials were carried out with an adapted commercial harvester baler and the storage of the bales was performed indoors during 1-7 days, 15-30 days and 100-120 days. Afterwards, the bales were crushed $(30 \mathrm{~mm})$ and distilled in a 30 litre stainless steel still with saturated steam ( 0.5 bar). The essential oil components were identified by GC-MS and quantified by GC-FID. The storage of mechanically harvested Cistus ladanifer does not decrease the oil yield of steam distillation on a pilot scale. However, it leads to differences in the quantitative composition of the essential oils, decreasing the total monoterpene compounds content and increasing that of oxygenated sesquiterpenes, especially when the biomass is stored for 100-120 days, without affecting its qualitative composition.
\end{abstract}

Keywords: Cistus ladanifer L.; distillation; essential oil; mechanised harvesting; pilot plant; rockrose

\section{Introduction}

Cistus plants, also known as rockroses, are a Mediterranean native genus of shrubs included in the Cistaceae family. The Cistus genus contains 25 different species and most of them are very fragrant, sweet-smelling and secrete essential oils. Some of them, like Cistus ladanifer subspecies ladanifer L., also secrete labdanum, a sticky exudate covering leaves and young stems [1].

Cistus ladanifer grows on sunny, acidic siliceous soils, at altitudes usually below $1000 \mathrm{~m}$ and the plant is generally between 1 and $2 \mathrm{~m}$ high [2]. In the Mediterranean region, it has dominant nature, with adaptation to extreme environmental factors such as the ability to survive in low hydric and high solar exposition conditions [3-5]. Moreover, it is a pyrophyte plant $[6,7]$ and often forms dense scrub communities that produce phytotoxic compounds (likely allelopathic) that may have inhibitory effects on the herbaceous understorey [3,8-11]. Therefore, Cistus ladanifer can eliminate competition and become a colonising species. It usually covers great areas of burnt degraded forests, abandoned pastures and crops in Spain, Portugal, south of France and north of Morocco [3]. The biggest extensions of Cistus ladanifer wild shrublands can be found in Spain where, according to recent estimations, the species is present in more than 2 million hectares and is dominant in a little more than 460,000 ha [12] (Figure 1). 


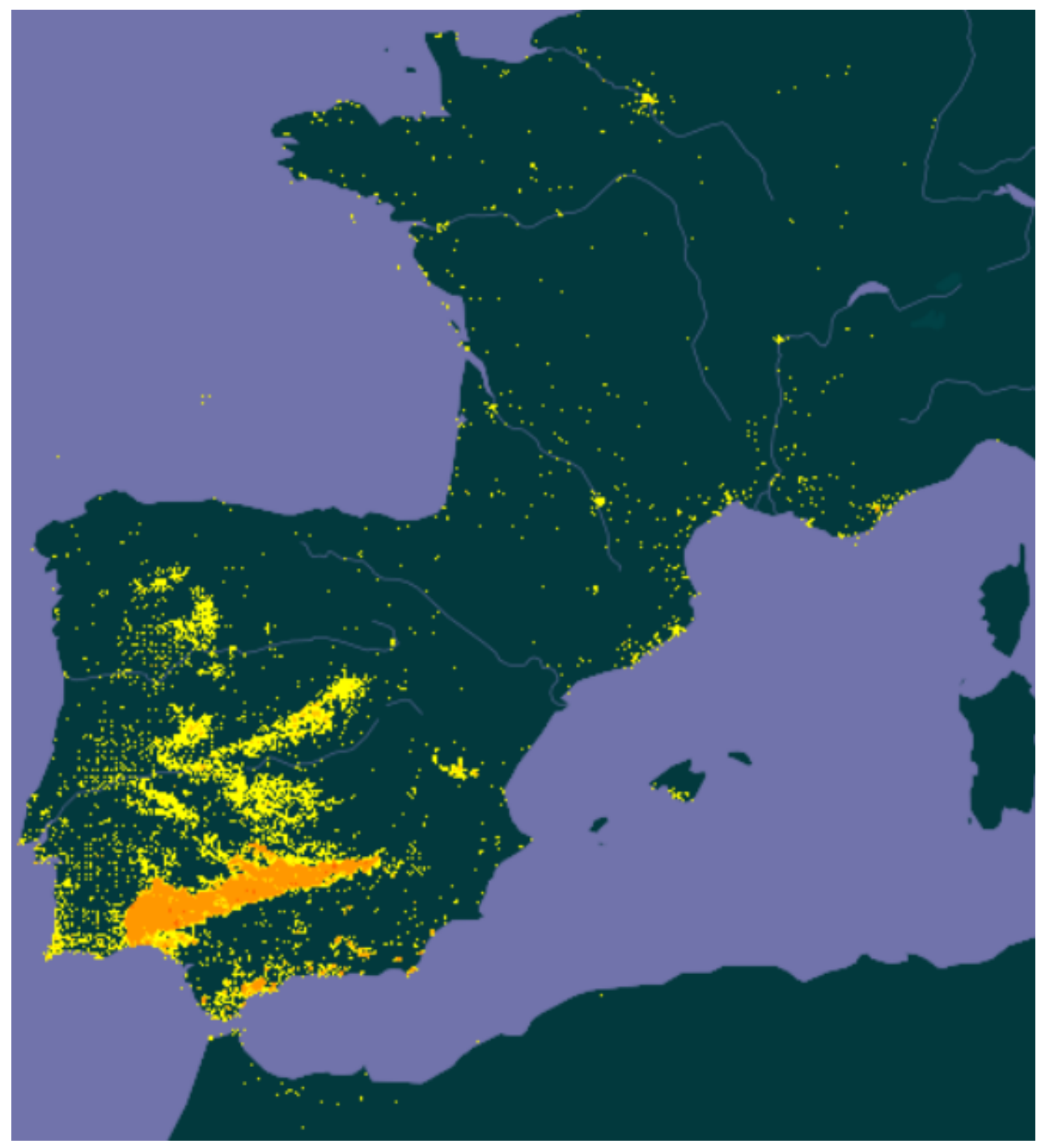

Figure 1. Distribution of Cistus ladanifer in Spain and other southern areas according to GBIF (Global Biodiversity Information Facility) [13].

Wildland fire is one of the major disturbance factors in Mediterranean ecosystems [7] and shrub clearings, together with other actions, have been shown to be an effective method to control fires and improve the land management of abandoned areas [14]. In this sense, and considering that Cistus ladanifer is a fire-prone plant species [6,7], clearings in areas where this plant is dominant and form dense and continuous shrubs could prevent fires and generate substantial amounts of sustainable raw material to obtain high added value products and bioenergy within the biorefinery concept.

Today, the harvesting of Cistus ladanifer biomass is concentrated in Spain, with little activity registered in Portugal, France and Morocco. Within Spain, the region of Andalusia is the main producer [15], but there is great potential in other regions such as Extremadura, Castilla La Mancha and Castilla y León (Western and Central regions). Considering the literature [15] and the result of a consultation with the main producer of Cistus ladanifer essential oil in Spain according to REACH (Registration, Evaluation and Authorization of Chemicals) [16] (Biolandes), the annual harvest of this biomass is between 10,000 and 20,000 tonnes.

Cistus ladanifer secretes a large amount of exudate from its leaves and photosynthetic stems through trichomes. This exudate is characterised by two families of secondary metabolites, flavonoids and diterpenoids [17], and it plays an important ecophysiological 
role [18] which depends on the concentration of these metabolites, whose synthesis is conditioned not only by environmental factors but also by an intrapopulation variation [17].

Although the typical product obtained from the plant is the labdanum gum, other products can be produced from Cistus ladanifer. Labdanum gum can be obtained by immersion of the aerial parts of the plant in warm carbonated water followed by acidification of the medium [19]. This method is widely used in small artisanal devices and in some small processing factories in Southern Spain [20] and currently the total estimated annual production of labdanum gum varies between 200 and $600 \mathrm{t} /$ year (communication from the company Biolandes), with six companies registered in the REACH [16]. If the labdanum gum is distilled, labdanum oil is obtained. On the contrary, if the gum undergoes an alcoholic extraction followed by concentration, labdanum resinoid is produced. The plant exudates can also be extracted using solvents. Therefore, the Cistus concrete is produced by solvent extraction of the plant aerial parts and subsequent elimination of the solvent by concentration of the extract, and the Cistus absolute is obtained by washing the concrete with ethanol, followed by filtration to eliminate the waxes and concentration of the alcoholic phase [19]. Finally, Cistus essential oil and hydrolate (also referred to as hydrosol or floral water), are obtained by hydrodistillation or steam distillation of the leaves and stems. The essential oil yields are very low and the current market prices may exceed $400 € / \mathrm{kg}$ [21]. The global production of essential oil is estimated to be between 1 and $10 \mathrm{t} /$ year, considering the result of a consultation with the only producer registered in the REACH with more than $1 \mathrm{t} /$ year [16] (Biolandes), although higher estimations (50-100 $t$ /year) have been made in the literature consulted [22]. It must also be noted that, although a significant part of the essential oil is produced in small steam distillation plants, the quantity of $50 \mathrm{t}$ /year should require at least an annual plant harvest of more than 50,000 t only for steam distillation, and this is not realistic according to the consulted companies (Biolandes and El Jarpil).

The essential oil has an increasing potential use not only in perfumery and cosmetics industries but also in aromatherapy, pharmaceutical, agricultural and food industries $[1,3,23,24]$, mainly due to its antimicrobial and antioxidant activities.

The most used technique to obtain essential oils on an industrial scale is steam distillation. As far as we know, very few studies on distillation of Cistus ladanifer on an industrial scale have been published. Typical yield values between $0.1 \%$ and $0.3 \%$ have been reported by Ruiz García et al. [21] and some industrial producers consulted (Biolandes and El Jarpil) consider that a common yield value with fresh biomass is close to $0.1 \%$. Experiences carried out in steam distillation pilot plants have also been poorly published, with yield values between $0.01 \%$ and $0.04 \%$ obtained with $100 \mathrm{~kg}$ of plants in a stainless steel distiller of $1100 \mathrm{~L}$ during $1.5 \mathrm{~h}$ at $0.5 \mathrm{bar}$ [25]. However, there are many studies where the distillation of this plant is performed on a laboratory scale through hydrodistillation by Clevenger's apparatus [25-30], with oil yields between $0.08 \%$ and $0.6 \%$.

The low yields obtained during Cistus ladanifer distillation in the industry entail the use of large quantities of biomass whose harvesting is usually carried out during a short period of time, from July to October [4]. The plants are currently manually harvested, this being very hard work as it is performed during the hottest days. Teams of harvesters cut the twigs using a sickle, bundle them up and pile them into cars and horse-drawn carts. Since the harvesting period is short, peaks of worker demand can be too high to be covered by the labour market. In this sense, mechanised harvesting could cause considerable improvements in the collection of this biomass, increasing the volume of harvested plants and improving the working conditions. However, the mechanised harvesting of rockrose is a complex matter mainly due to the stickiness of the plant.

In order to solve the aforementioned harvesting issues, the Centre for the Development of Renewable Energies attached to The Centre for Energy, Environmental and Technological Research (CEDER-CIEMAT) has adapted a commercial harvester baler BIOBALER WB55 and performed different harvesting assays in wild shrublands with promising results [31-35]. 
Taking into account a new framework in which mechanised harvesting is used in a sustainable way and higher harvesting yields are obtained in comparison to manual labour, higher storage periods before the distillation would be needed to carry out an appropriate management of the Cistus ladanifer logistics. The mechanised harvesting assays in Cistus ladanifer shrubland performed by CEDER-CIEMAT have allowed workers to collect the aboveground plant biomass in round big bale format and store the bales for long periods of time. The effect of the storage of this plant on the steam distillation process has not been reported previously. Therefore, the objective of this work is to study the influence of the storage period of mechanically harvested Cistus ladanifer bales on the distillation yield and on the essential oil composition in a pilot scale steam distillation plant.

\section{Results}

\subsection{Distillation Tests}

Cistus ladanifer bales from mechanised harvesting, with an average weight of $359 \mathrm{~kg}$ of wet matter per bale and an average moisture content of $30.7 \%$, were stored indoors under good ventilation conditions to prevent mould growth during the storage time. After the storage period, the bales were milled at $30 \mathrm{~mm}$ and distilled using the operating conditions shown in Section 4.2. The different processes carried out can be seen in Figure 2.

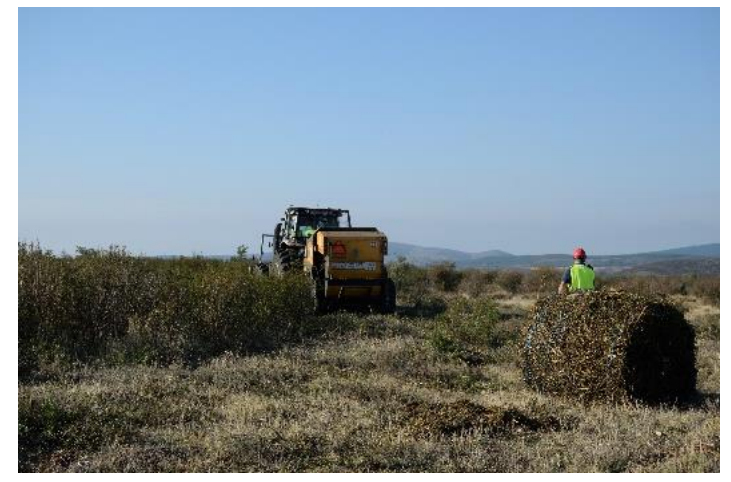

(a)

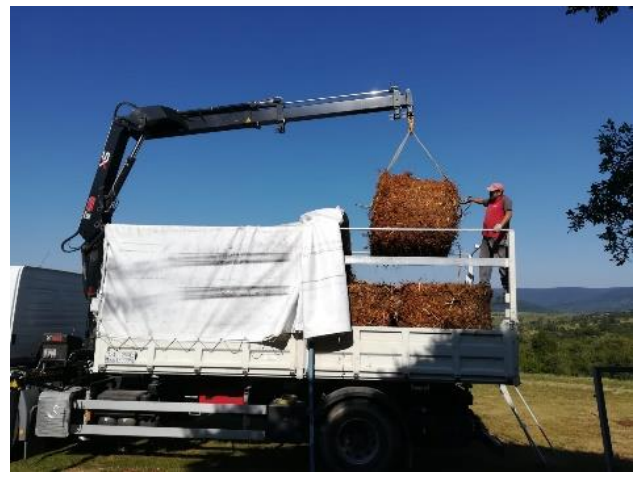

(b)

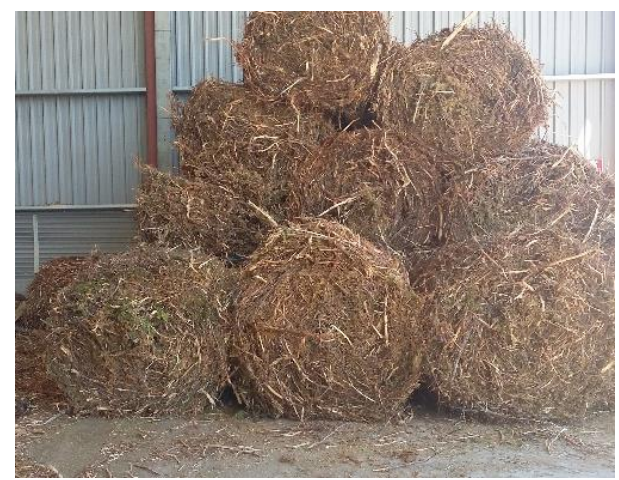

(c)

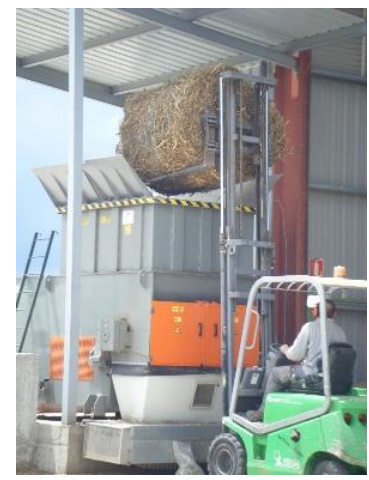

(d)

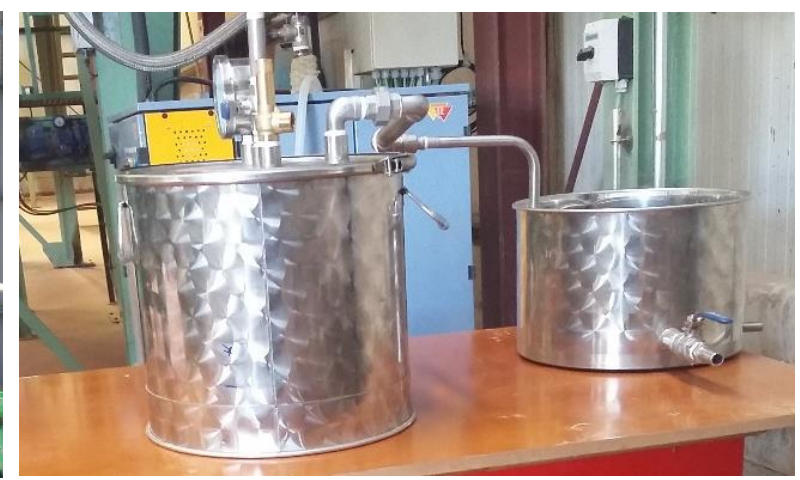

(e)

Figure 2. Processes carried out during the pretreatment of the plant material: (a) mechanised harvesting of Cistus ladanifer, (b) transport of the bales, (c) indoor storage, (d) crushing of the bales and (e) distillation of the milled biomass.

The yield obtained from essential oil distillation tests, expressed in weight percentage and referred to dry plant, is shown in Table 1. 
Table 1. Essential oil yields obtained in the batch steam distillations with stored Cistus ladanifer.

\begin{tabular}{cccccc}
\hline $\begin{array}{c}\text { Storage Time } \\
\text { (Days) }\end{array}$ & $\begin{array}{c}\text { Moisture Content } \\
(\mathbf{\%}, \mathbf{w . m})\end{array}$ & $\begin{array}{c}\text { Yield } \\
(\mathbf{\%}, \mathbf{d} . \mathbf{b} .)\end{array}$ & Aver. & Std. dev. & Rel. std. dev. \\
\hline 1 & 32.0 & 0.063 & & & \\
2 & 30.9 & 0.082 & & & \\
4 & 30.2 & 0.088 & & & \\
7 & 29.8 & 0.068 & & & \\
$1-7$ & 29.7 & 0.082 & & & \\
15 & 28.8 & 0.055 & & & \\
20 & 30.0 & 0.060 & & & \\
30 & & & 0.066 & & \\
$15-30$ & 15.8 & 0.050 & & & \\
100 & 15.2 & 0.060 & & & \\
110 & 15.2 & 0.047 & & & \\
120 & & & 0.052 & 0.0068 & \\
$100-120$ & & & & & \\
\hline
\end{tabular}

w.m.: wet matter; d.b.: dry basis; Aver.: average; Std. dev.: standard deviation; Rel. std. dev.: relative standard deviation.

Within each one of the periods considered (1-7 days, 15-30 days and 100-120 days), the variability between distillations was rather high, as can be noticed in the values of the relative standard deviation $(15.5 \%$ in the first period, $21.9 \%$ in the second period and $13.0 \%$ in the third one). It can be considered a normal variability between bales, related to variations in the proportion of young twigs and wood, rather than because of the time that elapses after harvesting.

Although a decreasing trend was observed in the essential oil yield, the statistical analysis of the data obtained showed that this decrease was not significant at the $95.0 \%$ confidence level, since $p$-value of the F-test was 0.0911 , greater than 0.05 .

\subsection{Essential Oil Composition}

The essential oils corresponding to the same storage period were blended and analysed as explained in Section 4.3. Cistus oil is one of the most complex essential oils, composed of more than 250 substances of many chemical classes. The main components identified and their quantification using the relative area percentage are shown in Table 2, where it can be observed that monoterpene hydrocarbons and oxygenated sesquiterpenes were the principal phytochemical groups in the essential oils here analysed.

Among the monoterpene hydrocarbons identified in the three periods analysed (0-7 days, $15-30$ days and 100-120 days, respectively), $\alpha$-pinene was the main compound $(49.65 \%, 47.42 \%$ and $46.67 \%)$ followed by camphene $(2.60 \%, 2.49 \%$ and $2.56 \%)$, limonene $(2.08 \%, 1.81 \%$ and $1.52 \%)$ and $p$-cymene $(1.47 \%, 1.26 \%$ and $1.33 \%)$. Considering the oxygenated monoterpenes, bornyl acetate $(2.71 \%, 2.32 \%$ and $2.48 \%)$, followed by transpinocarveol $(1.56 \%, 1.59 \%$ and $0.99 \%)$ can be highlighted. With regard to the sesquiterpene hydrocarbons, alloaromadendrene $(1.50 \%, 1.13 \%$ and $1.68 \%)$ was the main compound identified. In addition, finally, if the oxygenated sesquiterpenes are considered, viridiflorol $(10.03 \%, 11.98 \%$ and $12.50 \%)$, followed by ledol $(2.85 \%, 3.41 \%$ and $3.51 \%)$ were the most abundant compounds. The chemical structures of the abovementioned main compounds are shown in Figure 3. 
Table 2. Main components ( $\geq 0.3 \%)$ of Cistus ladanifer essential oil analysed by GC-MS and GC-FID.

\begin{tabular}{|c|c|c|c|c|c|}
\hline Component & $\mathbf{R I}_{\text {cal }}$ & $\mathbf{R I}_{\text {ref }}$ & $\begin{array}{c}\text { 0-7 Days } \\
\text { Rel. Area (\%) }\end{array}$ & $\begin{array}{l}\text { 15-30 Days } \\
\text { Rel. Area (\%) }\end{array}$ & $\begin{array}{l}\text { 100-120 Days } \\
\text { Rel. Area (\%) }\end{array}$ \\
\hline Total monoterpene hydrocarbons & & & 60.92 & 58.23 & 56.50 \\
\hline$\alpha$-pinene & 1020 & 1025 & 49.65 & 47.42 & 46.67 \\
\hline Camphene & 1062 & 1069 & 2.60 & 2.49 & 2.56 \\
\hline$\beta$-pinene & 1108 & 1110 & 0.61 & 0.87 & 0.56 \\
\hline Sabinene & 1121 & 1122 & 0.37 & 0.38 & 0.47 \\
\hline Verbenene & 1125 & 1124 & 1.20 & 0.93 & 0.47 \\
\hline$\alpha$-terpinene & 1182 & 1178 & 0.33 & 0.41 & 0.42 \\
\hline Limonene & 1203 & 1198 & 2.08 & 1.81 & 1.52 \\
\hline$\beta$-phellandrene & 1212 & 1209 & 0.61 & 0.41 & 0.29 \\
\hline$\gamma$-terpinene & 1252 & 1245 & 0.79 & 0.87 & 0.86 \\
\hline p-cymene & 1278 & 1279 & 1.47 & 1.26 & 1.33 \\
\hline$\alpha$-terpinolene & 1294 & 1290 & 0.21 & 0.36 & 0.22 \\
\hline Total oxygenated monoterpenes & & & 10.34 & 10.37 & 8.15 \\
\hline 1,8-Cineole & 1217 & 1211 & 0.30 & 0.26 & 0.21 \\
\hline 2,2,6-Trimethylcyclohexanone & 1328 & 1328 & 0.46 & 0.40 & 0.41 \\
\hline$\alpha$-campholenal & 1498 & 1496 & 0.18 & 0.73 & 0.16 \\
\hline Isopinocamphone & 1562 & & 0.63 & 0.59 & 0.42 \\
\hline Pinocarvone & 1589 & 1586 & 1.04 & 0.92 & 0.75 \\
\hline Bornyl acetate & 1595 & 1592 & 2.71 & 2.32 & 2.48 \\
\hline Terpinen-4-ol & 1613 & 1601 & 0.76 & 0.54 & 0.47 \\
\hline Myrtenal & 1643 & 1635 & 0.38 & 0.32 & 0.33 \\
\hline trans-pinocarveol & 1668 & 1664 & 1.56 & 1.59 & 0.99 \\
\hline Myrtenyl acetate & 1699 & 1698 & 0.57 & 0.53 & 0.56 \\
\hline Borneol & 1704 & 1701 & 0.38 & 0.35 & 0.28 \\
\hline Total sesquiterpene hydrocarbons & & & 6.54 & 6.05 & 6.63 \\
\hline$\alpha$-ylangene & 1497 & 1490 & 0.53 & 0.53 & 0.60 \\
\hline$\alpha$-copaene & 1506 & 1492 & 0.78 & 0.79 & 0.81 \\
\hline Alloaromadendrene & 1665 & 1661 & 1.50 & 1.13 & 1.68 \\
\hline Ledene & 1704 & 1704 & 0.21 & 0.24 & 0.37 \\
\hline$\alpha$-muurolene & 1742 & 1740 & 0.46 & 0.51 & 0.51 \\
\hline$\delta$-cadinene & 1777 & 1772 & 0.97 & 1.13 & 1.11 \\
\hline$\alpha$-calacorene & 1924 & 1921 & 0.36 & 0.42 & 0.49 \\
\hline Total oxygenated sesquiterpenes & & & 14.57 & 17.81 & 18.64 \\
\hline Palustrol & 1952 & 1938 & 0.13 & 0.43 & 0.45 \\
\hline Ledol & 2059 & 2057 & 2.85 & 3.41 & 3.51 \\
\hline Viridiflorol & 2113 & 2104 & 10.03 & 11.98 & 12.50 \\
\hline Spathulenol & 2146 & 2144 & 0.34 & 0.39 & 0.41 \\
\hline T-muurolol & 2199 & 2191 & 0.49 & 0.63 & 0.70 \\
\hline Others & & & 2.02 & 1.69 & 2.38 \\
\hline Sclareoloxide & 2278 & & 0.34 & 0.61 & 0.85 \\
\hline Total identified & & & 94.39 & 94.15 & 92.30 \\
\hline
\end{tabular}

RI: retention index relative to $\mathrm{C}_{6}-\mathrm{C}_{30} n$-alkane on DB-WAX column (cal: calculated, ref: reference, according to Pherobase database [36]); Rel. area: relative peak areas calculated by GC-FID. 


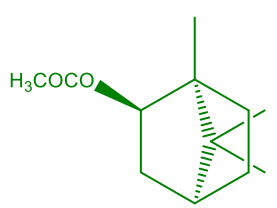

Bornyl acetate

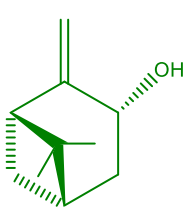

trans-pinocarveol

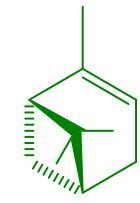

$\alpha$-pinene

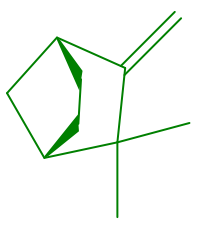

Camphene

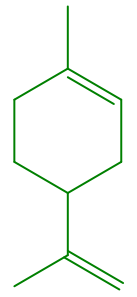

Limonene

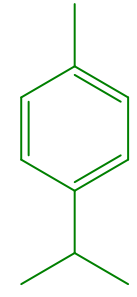

p-cymene

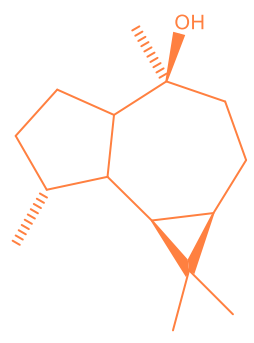

Viridiflorol

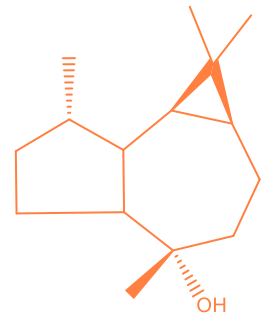

Ledol

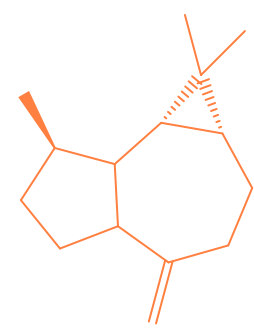

Alloaromadendrene

Figure 3. Main compounds of essential oils obtained from stored Cistus ladanifer.

\section{Discussion}

Regarding the distillation tests, the average essential oil yields are lower than those obtained by other authors who used only manually collected twigs or leaves and hydrodistilled them in a Clevenger apparatus (laboratory scale), with yield values as much as $0.6 \%$ [29]. However, they are higher than the values shown by Tavares et al. [25] for the steam distillation in a pilot plant (0.01-0.04\%).

Although the decrease in the essential oil yield over the period considered is not statistically significant, a decrease of $12.0 \%$ with regard to the fresh plant distillation is observed when the storage is between 15 and 30 days, and a decrease of $30.7 \%$ when the storage period is between 100 and 120 days. Considering the literature [37], it could be due to the volatilisation of some compounds during the storage or to the biomass biodegradation caused by physiological deterioration and other factors. The first alternative seems to be a more likely reason if we attend to the reduction in the monoterpenes from $60.92 \%$ to $56.50 \%$, and oxygenated monoterpenes, from $10.34 \%$ to $8.15 \%$, as can be seen in Table 2. In addition, neither mouldiness nor other visual alterations were observed after the storage, and no temperature increases were detected inside the bales either.

The composition of Cistus ladanifer essential oil depends on several factors, including the origin of the plant, the season when the harvest was carried out or the oil extraction method used [1,3,25-27]. In this sense, different compositions have been found in literature. According to Ruiz García et al. [21], commercial essential oils usually show high $\alpha$-pinene content, it being desirable not to exceed $30 \%$, and sometimes using a partial removal of this component. Other major components are also shown, such as trans-pinocarveol, with limits between $2.0 \%$ and $7.0 \%$, ledene, ranging between $1.0 \%$ and $6.0 \%$ and viridiflorol, with typical values between $1.5 \%$ and $3.5 \%$. Other authors that have analysed commercial Cistus essential oils have reported results for Spanish essential oils [27] with $\alpha$-pinene (48.9-50.0\%), camphene (2.4-5.0\%), 2,2,6-trimethyl cyclohexanone (1.5-2.0\%), bornyl acetate (1.5-3.1\%), trans-pinocarveol (1.7-2.8\%), viridiflorol (1.1-1.7\%) and ledene (1.4-3.7\%) as the main compounds. The analysis of commercial Portuguese essential oils [25] has shown the same major compounds and different limits, i.e., $\alpha$-pinene (29.8-59.5\%), camphene (2.6-14.7\%), 2,2,6- trimethyl cyclohexanone (0.4-3.4\%), bornyl acetate (2.1-6.1\%), trans-pinocarveol $(1.8-5.9 \%)$, viridiflorol $(0.8-1.9 \%)$ and ledene $(0.3-4.5 \%)$. On the other hand, considering literature where parameters regarding plants, harvesting, oil extraction methods and oil analysis are studied, different compositions of the oil have been found. Therefore, very 
low $\alpha$-pinene and camphene contents, around $2 \%$ and $0.1 \%$, respectively [26,27], transpinocarveol contents up to $10.9 \%$ [26] and viridiflorol contents higher than $15 \%[26,27,38,39]$ are reported in some of the samples analysed. On the other hand, especially high globulol values [27], between 3.1\% and 5.0\%, 1-8 cineole values (19.3\%) [38], $\gamma$-terpinene (6.1\%) [38] and $\gamma$-gurjunene (14.6\%) [39] are shown in some of the studies.

In this sense, the comparison of the data obtained in the present work with analyses found in literature and market data from industrial scale, where the conditions to obtain the essential oil can be different, shows quantitatively relevant differences, mainly in the content of key sesquiterpene alcohols like viridiflorol, whose content is higher in these experiments than in most of the analyses of commercial and non-commercial oils reported.

The total compounds identified in the essential oils analysed are similar in all three cases $(94.39 \%, 94.15 \%$ and $92.30 \%)$. Moreover, the biomass origin and the pretreatment and distillation operating conditions remained constant in all the experiments. Consequently, it can be highlighted that when the storage period increases, the percentages of total monoterpene hydrocarbons and total oxygenated monoterpenes tend to decrease while the percentages of total oxygenated sesquiterpenes tend to increase, especially when the samples corresponding to $0-7$ days and $100-120$ days (14.57\% vs. $18.64 \%)$ are compared. Taking into account the different compounds, $\alpha$-pinene, verbenene, limonene and $\beta$ phellandrene are the monoterpene hydrocarbons with the higher decrease. Regarding the sesquiterpene hydrocarbons, the change is not remarkable in any of the compounds identified. Finally, within the oxygenated sesquiterpenes, the increase in viridiflorol and ledol can be highlighted. However, it is interesting to note that no qualitative differences were observed in the composition of the essential oil in the different storage periods.

Future research is necessary to study the influence of the density of Cistus ladanifer bales on the storage, the essential oil yield and its chemical composition. Similarly, additional research to determine if the storage outdoors, keeping bales dry, produces significant changes in the quantity and quality of the Cistus essential oil is planned.

\section{Materials and Methods}

\subsection{Plant Material}

The plant material was obtained with a harvester baler system (BIOBALER WB55, Chesterville, QC, Canada). This equipment, powered by a $154 \mathrm{~kW}$ tractor (Valtra T194D, Suolahti, Finland), includes a harvester unit that cuts standing shrubs at an approximate height of $15 \mathrm{~cm}$ above the ground, and leads vegetation to a cylindrical baling system that compresses the biomass into round big bales. This machine was acquired in 2015 and tested with different shrub vegetation and terrain conditions in the ENERBIOSCRUB project between 2015 and 2018 [40]. Some tests were carried out in Cistus laurifolius shrublands, a species similar to Cistus ladanifer but with much less content of sticky exudates [33].

The study was performed on 12.97 ha of abandoned cropland covered by rockrose (Cistus ladanifer) in Hiendelaencina-Guadalajara (Spain), at an altitude of $1030 \mathrm{~m}$ above sea level in October 2018. The site has cool Mediterranean climate, according to Köppen classification, with an annual average rainfall of $585 \mathrm{~mm}$, average temperature of the warmest month below $22{ }^{\circ} \mathrm{C}$ and 69 frost days per year. Soil conditions were similar in the whole area, with gentle slope, low terrain roughness and no stoniness. The area was mainly covered by rockrose shrubs with a mean height of $0.5 \mathrm{~m}$, estimated age between 5 and 10 years and average ground crown cover of $40 \%$.

After the harvesting, the bales were transported to CEDER-CIEMAT. Then, four samples were taken from four different bales and the moisture content of the biomass was analysed following the standard ISO 18134-2:2017 (Solid biofuels-Determination of moisture content-Oven dry method-Part 2: Total moisture-Simplified method). Afterwards, the bales were stored indoors during three different periods: 1-7 days (just harvested), 15-30 days (less than one month from harvest) and 100-120 days (long storage period). 
After the storage period, the corresponding bales were crushed to a size of $30 \mathrm{~mm}$ by means of a shredder ( $90 \mathrm{~kW}$, slow rotating single-shaft type, SILMISA, Onil, Spain), just before the distillation tests.

\subsection{Distillation Tests}

Ten water steam distillation tests were performed, each one corresponding to a different storage time: $1,2,4,7,15,20,30,100,110$ and 120 days. Four consecutive samples of $30 \mathrm{~mm}$ milled Cistus ladanifer (5 $\mathrm{kg}$ each) were distilled for each one of the tests. The essential oil obtained was accumulated and the yield was calculated for the whole distillation process. Afterwards, the essential oils corresponding to each one of the storage periods (1-7 days, 15-30 days and 100-120 days) were blended and analysed.

A 30 litre stainless steel still and saturated steam ( 0.5 bar) produced in an electric boiler (ETE, Madrid, Spain) were used during the batch steam distillation tests. The steam flow was $15 \mathrm{~kg} / \mathrm{h}$ and the extraction duration $30 \mathrm{~min}$ per sample distilled. Time was measured from the moment the first drop of distillate fell. The temperature inside the still was kept constant at $98^{\circ} \mathrm{C}$. The hydrolate and the essential oil were separated by density using a glass Florentine flask and the samples were collected in glass flasks. The essential oils were dried over anhydrous sodium sulphate. After filtration they were weighed and stored at $4{ }^{\circ} \mathrm{C}$ until further analysis. The oil yield was calculated as a percentage (weight/weight) on a biomass dry basis.

\subsection{Essential Oil Analysis}

The essential oil components were analysed by GC (FID)-MS, using the relative area percentage. The used apparatus were Agilent HP 8890/5977 (GC-MS) and Agilent HP 8890 (GC-FID) (Agilent Technologies, Santa Clara, CA, USA), both equipped with DB-WAX UI fused silica columns $(60 \mathrm{~m} \times 0.25 \mathrm{~mm}$ inner diameter, film thickness $0.5 \mu \mathrm{m})$ and retention time locking. The column temperature program was $50{ }^{\circ} \mathrm{C}$ for a duration of $6 \mathrm{~min}$, increase of $2{ }^{\circ} \mathrm{C} / \mathrm{min}$ to $190^{\circ} \mathrm{C}$, then $4{ }^{\circ} \mathrm{C} / \mathrm{min}$ increase to $220^{\circ} \mathrm{C}$, which was maintained for $10 \mathrm{~min}$ and, finally, $4{ }^{\circ} \mathrm{C} / \mathrm{min}$ increase to $250^{\circ} \mathrm{C}$, which was maintained for $10 \mathrm{~min}$. The carrier gas was helium at a variable flow rate and a head pressure of $30.75 \mathrm{psi}$. The injection volume was $0.1 \mu \mathrm{L}$ and split mode injection (ratio 1:100) was employed. Injector and detector temperatures were $240{ }^{\circ} \mathrm{C}$. GC-MS was performed with the same capillary column, carrier gas and operating conditions described for GC analysis. Mass spectra were taken over the $\mathrm{m} / \mathrm{z}$ range 33-350 with an ionisation voltage of $70 \mathrm{eV}$.

The individual components were identified by MS and their identity was confirmed by comparison of their Kovats retention index calculated using co-chromatographed standard hydrocarbons relative to $\mathrm{C}_{6}-\mathrm{C}_{30} n$-alkanes and mass spectra with reference samples and those of the computer libraries (NIST 14, Wiley 10 and Chromessence library built through standards injection) and available data in the literature [41].

\subsection{Statistical Analysis}

Statistical analysis of the data set corresponding to the essential oil yields across the storage times was performed using Statgraphics Centurion XVII.I. A variance analysis (ANOVA) was used to determine statistically significant differences across the storage periods. Statistically significant difference at $p$-value of the F-test below 0.05 was considered.

\section{Conclusions}

The storage of Cistus ladanifer L. bales from mechanised harvesting during 100-120 days does not significantly decrease the essential oil yield. Consequently, a mechanised harvesting of this species together with the storage of the plants could be contemplated by the industry to increase the volume of harvested plants and to improve the working conditions during harvesting, compared to the traditional manual harvesting.

On the other hand, although in the different periods tested there was a decrease in the content of the total monoterpene compounds and an increase in the oxygenated 
sesquiterpenes, mainly during the 100-120 days of storage, no differences were found in the qualitative composition of the essential oils obtained in the three storage periods studied.

Author Contributions: Conceptualization, I.M. and L.S.E.; methodology, L.S.E.; validation, I.M., M.A.B. and L.S.E.; formal analysis, I.M. and A.R.; investigation, A.R. and L.S.E.; writing-original draft preparation, I.M.; writing—review and editing, M.A.B. and L.S.E.; visualization, I.M., M.A.B.; supervision, L.S.E.; project administration, L.S.E.; funding acquisition, L.S.E. All authors have read and agreed to the published version of the manuscript.

Funding: In this work, equipment co-funded by the European Regional Development Fund has been used: a biomass conditioning and pre-treatment line (project CIEM09-3E-275) and a biomass harvester baler machine (project CIEM13-3E-2505).

Institutional Review Board Statement: Not applicable.

Informed Consent Statement: Not applicable.

Data Availability Statement: Not applicable.

Acknowledgments: The authors wish to express their appreciation and gratitude to the Town Hall of Hiendelaencina (Guadalajara, Spain) for their support in the harvesting tests, and to the companies Biolandes and El Jarpil for the information about the essential oil industry that they have shared.

Conflicts of Interest: The authors declare no conflict of interest. The funders had no role in the design of the study; in the collection, analyses, or interpretation of data; in the writing of the manuscript, or in the decision to publish the results.

Sample Availability: The data leading to the results of this work are available from the authors upon reasonable request.

\section{References}

1. Barrajón-Catalán, E.; Tomás-Menor, L.; Morales-Soto, A.; Martí, B.N.; Saura López, D.; Segura-Carretero, A.; Micol, V. Chapter 74-Rockroses (Cistus sp.) oils. In Essential Oils in Food Preservation, Flavor and Safety, 1st ed.; Academic Press: Cambridge, MA, USA, 2015; pp. 649-658. [CrossRef]

2. Gómez-Serrano, V.; Valenzuela-Calahorro, C.; Pastor-Villegas, J. Characterization of rockrose wood, char and activated carbon. Biomass Bioenergy 1993, 4, 355-364. [CrossRef]

3. Frazao, D.F.; Raimundo, J.R.; Domingues, J.L.; Quintela-Sabarís, C.; Goncalves, J.C.; Delgado, F. Cistus ladanifer (Cistaceae): A natural resource in Mediterranean-type ecosystems. Planta 2018, 247, 289-300. [CrossRef] [PubMed]

4. Raimundo, J.R.; Frazao, D.F.; Domingues, J.L.; Quintela-Sabarís, C.; Dentinho, T.P.; Anjos, O.; Alves, M.; Delgado, F. Neglected Mediterranean plant species are valuable resources: The example of Cistus ladanifer. Planta 2018, 248, $1351-1364$. [CrossRef] [PubMed]

5. Alías Gallego, J.C.; González Caro, J.; Hinojal Campos, V.; Chaves Lobón, N. Effect of leaf litter from Cistus ladanifer L. on the germination and growth of accompanying shrubland species. Plants 2020, 9, 593. [CrossRef] [PubMed]

6. Luna, B. Fire and summer temperatures work together breaking physical seed dormancy. Sci. Rep. 2020, 10, 1-10. [CrossRef]

7. Martín-Pinto, P.; Vaquerizo, H.; Peñalver, R.; Olaizola, J.; Oria-de-Rueda, J.A. Early effects of a wildfire on the diversity and production of fungal communities in Mediterranean vegetation types dominated by Cistus ladanifer and Pinus pinaster in Spain. For. Ecol. Manag. 2006, 225, 296-305. [CrossRef]

8. Herranz, J.M.; Ferrandis, P.; Copete, M.A.; Duro, E.M.; Zalaca, A. Effect of allelopathic compounds produced by Cistus ladanifer on germination of 20 Mediterranean taxa. Plant Ecol. 2006, 184, 259-272. [CrossRef]

9. Scognamiglio, M.; D'Ambrosca, B.; Esposito, A.; Pacifico, S. Plant growth inhibitors: Allelopathic role or phytotoxic effects? Focus on Mediterranean biomes. Phytochem. Rev. 2013, 12, 803-830. [CrossRef]

10. Du Plessis, S.P.; Rink, A.; Goodall, V.; Kaplan, H.; Jubase, N.; Van Wyk, E. Assessment and management of the invasive shrub, Cistus ladanifer, in South Africa. S. Afr. J. Bot. 2018, 117, 85-94. [CrossRef]

11. Dias, A.S.; Costa, C.T.; Dias, L.S. Allelopathic plants. XVII. Cistus ladanifer L. Allelopath. J. 2005, 16, 1-30.

12. Montero, G.; López-Leiva, C.; Ruiz-Peinado, R.; López-Senespleda, E.; Onrubia, R.; Pasalodos, M. Producción De Biomasa Y Fijación De Carbono Por Los Matorrales Españoles Y Por El Horizonte Orgánico Superficial De Los Suelos Forestales. Ministerio De Agricultura, Pesca Y Alimentación: Spain, 2020. Available online: https:/ /www.mapa.gob.es/es/desarrollo-rural/ publicaciones/publicaciones-de-desarrollo-rural/librobiomasadigital_tcm30-538563.pdf (accessed on 26 October 2020).

13. Checklist Dataset. Cistus ladanifer L. in GBIF Secretariat (2019). GBIF Backbone Taxon. 2011. [CrossRef]

14. Lasanta, T.; Khorchani, M.; Pérez-Cabello, F.; Errea, P.; Sáenz-Blanco, R.; Nadal-Romero, E. Clearing shrubland and extensive livestock farming: Active prevention to control wildfires in the Mediterranean mountains. J. Environ. Manag. 2018, 227, 256-266. [CrossRef] [PubMed] 
15. Alves-Ferreira, J.; Duarte, L.C.; Lourenco, A.; Roseiro, L.B.; Fernandes, M.C.; Pereira, H.; Carvalheiro, F. Distillery residues from Cistus ladanifer (rockrose) as feedstock for the production of added-value phenolic compounds and hemicellulosic oligosaccharides. Bioenerg. Res. 2019, 12, 347-358. [CrossRef]

16. REACH Registration Dossier. Essential Oil of Cistus ladaniferus L (Cistaceae) Obtained from Stems and Leaves by Distillation. Available online: https:/ / echa.europa.eu/registration-dossier/- /registereddossier/21887 (accessed on 12 December 2020).

17. Valares Masa, C.; Alías Gallego, J.C.; Chaves Lobón, N.; Sosa Díaz, T. Intra-Population Variation of Secondary Metabolites in Cistus ladanifer L. Molecules 2016, 21, 945. [CrossRef] [PubMed]

18. Valares Masa, C.; Sosa Díaz, T.; Alías Gallego, J.C.; Chaves Lobón, N. Quantitative variation of flavonoids and diterpenes in leaves and stems of Cistus ladanifer L. at different ages. Molecules 2016, 21, 275. [CrossRef]

19. Frija, L.M.T.; Alfonso, C.A.M. Supported acid-catalyzed flash vacuum thermolysis on the valorisation of labdanum resin. Biomass Bioenergy 2014, 71, 363-369. [CrossRef]

20. Martín Morgado, J.; Tapias, R.; Alesso, P. Producción de goma bruta de jara (Cistus ladanifer L.) en el suroeste de la Península Ibérica. In Proceedings of the IV Congreso Forestal Español, Zaragoza, Spain, 26-30 September 2005.

21. Ruiz García, M.R.; Cardenete, A.R.; Cardenete, J. Aceite esencial de Cistus. In El Mundo De Los Aceites Esenciales. La Guía Definitiva, 1st ed.; AMV Ediciones: Madrid, Spain, 2020; pp. 51-54.

22. Lubbe, A.; Verpoorte, R. Cultivation of medicinal and aromatic plants for specialty industrial materials. Ind. Crops Prod. 2011, 34, 785-801. [CrossRef]

23. Papaefthimiou, D.; Papanikolau, A.; Falara, V.; Givanoudi, S.; Kostas, S.; Kanellis, A.K. Genus Cistus: A model for exploring labdane-type diterpenes' biosynthesis and a natural source of high value products with biological, aromatic, and pharmacological properties. Front. Chem. 2014, 35, 1-19. [CrossRef]

24. Jerónimo, E.; Cachucho, L.; Soldado, D.; Guerreiro, O.; Bessa, R.J.B.; Alves, S.P. Fatty acid content and composition of the morphological fractions of Cistus ladanifer L. and its seasonal variation. Molecules 2020, 25, 1550. [CrossRef] [PubMed]

25. Tavares, C.S.; Martins, A.; Faleiro, M.L.; Miguel, M.G.; Duarte, L.C.; Gameiro, J.A.; Roseiro, L.B.; Figueiredo, A.C. Bioproducts from forest biomass: Essential oils and hydrolates from wastes of Cupressus lusitanica Mill. and Cistus ladanifer L. Ind. Crops Prod. 2020, 144, 112034. [CrossRef]

26. Mariotti, J.P.; Tomi, F.; Casanova, J.; Costa, J.; Bernardini, A.F. Composition of the essential oil of Cistus ladaniferus L. cultivated in Corsica (France). Flavour Fragr. J. 1997, 12, 147-151. [CrossRef]

27. Gomes, P.B.; Mata, V.G.; Rogrigues, A.E. Characterization of the Portuguese-grown Cistus ladanifer essential oil. J. Essent. Oil Res. 2005, 17, 160-165. [CrossRef]

28. Greche, H.; Mrabet, J.; Zrira, S.; Ismaïlï-Alaoui, M.; Benjilali, B.; Boukir, A. The volatiles of the leaf oil of Cistus ladanifer L. var. albiflorus and labdanum extracts of Moroccan origin and their antimicrobial activities. J. Essent. Oil Res. 2009, 21, 166-173. [CrossRef]

29. Guimaraes, R.; Sousa, M.J.; Ferreira, I.C.F.R. Contribution of essential oils and phenolics to the antioxidant properties of aromatic plants. Ind. Crops Prod. 2010, 32, 152-156. [CrossRef]

30. Bechlaghem, K.; Allali, H.; Benmehdi, H.; Aissaoui, N.; Flamini, G. Chemical analysis of the essential oils of three Cistus species growing in North-West of Algeria. Agric. Conspec. Sci. 2019, 84, 283-293.

31. Bados, R.; Esteban, L.S.; Corredor, R.; Maqueda, L.; Zamora, V.; Mediavilla, I.; Carrasco, J.E.; Blasco, I.; Calero, R.; Carrascosa, A.; et al. Scrub harvesting trials for energy purposes. In Proceedings of the 24th European Biomass Conference and Exhibition, Amsterdam, The Netherlands, 6-9 June 2016; pp. 270-273.

32. Bados, R.; Tolosana, E.; Esteban, L.S. Biomass collection from wildfire prevention treatment on rockrose shrublands with a harvester baler (Biobaler WB55) in Soria (Spain). In Proceedings of the 51st International Symposium of Forest MechanizationFORMEC 2018, Madrid, Spain, 24-28 September 2018; pp. 67-68.

33. Bados, R.; Tolosana, E.; Esteban, L.S. Evaluation of a harvester-baler system operating in a rockrose (Cistus laurifolius L.) shrubland. Croat. J. For. Eng. 2020, 41, 191-203. [CrossRef]

34. Mauri, P.V.; Cano, C.; Bados, R.; Plaza, J. Use of the essential oil of jara pringosa in the Sierra Norte from Madrid. In Proceedings of the 24th International Congress on Project Management and Engineering, Alcoy, Spain, 7-9 July 2020; p. 1216.

35. Mediavilla, I.; Bados, R.; Blázquez, M.A.; Esteban, L.S. Characterization of the essential oil and the biomass obtained by mechanised harvesting of Cistus ladanifer L. In Proceedings of the 28th European Biomass Conference and Exhibition, online, 6-9 July 2020; pp. 507-510.

36. The Pherobase: Database of Pheromones and Semiochemicals. Available online: https://www.pherobase.com/ (accessed on 8 March 2021).

37. Gingade, S. Influence of pre and post-harvest factors on yield and quality of medicinal and aromatic plants. In Medicinal and Aromatic Crops Conservation and Cultivation; AkiNik: Delhi, India, 2019; pp. 116-143.

38. Viuda-Martos, M.; Sendra, E.; Pérez-Alvarez, J.A.; Fernández-López, J.; Amensour, M.; Abrini, J. Identification of flavonoid content and chemical composition of the essential oils of Moroccan herbs: Myrtle (Myrtus communis L.), rockrose (Cistus ladanifer L.) and Montpellier cistus (Cistus monspeliensis L.). J. Essent. Oil Res. 2011, 23, 1-9. [CrossRef]

39. Benali, T.; Bouyahya, A.; Habbadi, K.; Zengin, G.; Khabbach, A.; Achbani, E.H.; Hammani, K. Chemical composition and antibacterial activity of the essential oil and extracts of Cistus ladaniferus subsp. ladanifer and Mentha suaveolens against phytopathogenic bacteria and their ecofriendly management of phytopathogenic bacteria. Biocatal. Agric. Biotechnol. 2020, 28, 101696. [CrossRef] 
40. Mediavilla, I.; Fernández, M.J.; Barro, R.; Borjabad, E.; Bados, R.; Esteban, L.S. Effect of mechanical harvesting on the chemical composition and combustion behaviour of shrub biomass. Energy 2020, 204, 117928. [CrossRef]

41. Adams, R.P. Identification of Essential Oil Components by Gas Chromatography/Mass Spectrometry, 4th ed.; Allured Publishing Corporation: Carol Stream, IL, USA, 2007. 